\section{1. 序論}

石炭火力発電を初めとする多くの石炭燃焼では熱効 率, 操作性から微粉炭燃焼方式が採用されている1)。 石炭燃焼に伴って, $\mathrm{SO}_{\mathrm{x}}, \mathrm{NO}_{\mathrm{x}}$ などの大気污染物が放 出されると同時に，石炭中の灰分および未然焼炭も排 出され，大気を污染する浮遊粒子状物質となる 2 ( 2$)$ 。 石炭中の灰分は炉内に残るスラグあるいはボトムアッ シュと，ばい煙と共に排出されるフライアッシュ（以 下F.A.) に大別される。未燃焼炭も微粒子であれば F.A.に含まれる。

F.A.はバグフィルターまたは, 電気集じん器によ つて捕集され，セメント原料などとして有効利用され るが9), F.A. 中, 粒径が $0.1-1 \mu \mathrm{m}$ 以下のサブミクロ ン粒子は両装置による捕集効率が悪く, かつ, 呼吸器 管を通して生体内に進入沈着し，健康に悪影響を与え

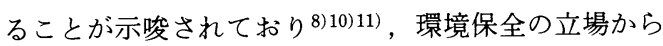
関心が寄せられている。したがって，このようなサブ ミクロンF.A.の生成機構を明らかにして，その生成 を抑制することは石炭利用の拡大を計る上で重要であ る。この内，未然焼炭は完全燃焼により消失が期待で きるので，石炭中，鉱物に由来するサブミクロン粒子 に対する検討が主たる課題となろら。

鉣物性サブミクロン粒子の生成には次の3つの機構 が考えられる3)12)。

(1)開裂粉化型：石炭中の鉱物が燃焼中に機械的にあ るいは熱分解により微粉化しサブミクロン粒子となる。 (2)原型維持型：石炭中の鉱物質粒子が原型を維持し たままサブミクロン粒子となる。

\footnotetext{
*1福岡県太宰府市大字向佐野字迎田 39

*2 機能物質科学研究所 春日市春日公園 6-1
}

福岡県衛生公害センター*1 下原 孝章 九州大学 $* 2$ 安藤 隆, 持田 勲

(3)揮発凝集型：石炭中の鉱物イオンあるいは極微小 粒子 $(<0.1 \mu \mathrm{m})$ が揮発, 凝集してサブミクロン粒子 となる。揮発性無機物は, このような粒子に沈着する こともありらる。

3つの機構の何れがおもに作用するかは石炭の炭種 や燃焼条件によって変化することが予想される。事実, F.A.の色調, 組成は上述の燃焼条件により大きく異 なることが知られている2) 4)13) 15)。

本研究ではサブミクロンF.A.生成の機構と防止の 方策を考察するため，3種の石炭を低温灰化および微 粉炭燃焼し, 生成するF.A. 相当の粒子の形状一組成を 調べ，両者を比較して相関を考察した。さらにイオン 交換により石炭中の金属イオンを除去した後，灰化あ るいは燃焼により生成するF.A.の変化を追跡した。 これらにより, サブミクロンF.A.の生成機構のいず れが主であるかが議論できよう。

\section{2. 実験方法}

2.1 石炭試料: 使用石炭およびその分析值を Table 1 に示す。微溶融瀝青炭であるAberdare, Miller炭および非溶融褐炭であるMowell炭を用いた。 これから石炭はおのおの窒素気流下で 60-200mesh 以下に粉砕, ふるい分け後, 常温, 減王下で乾燥した。

2.2 前処理: 石炭試料についてTable 2 に示した 溶媒を用いて脱鉱物質前処理を行った。石炭試料をこ れら溶媒と共に三ッロフラスコ内に入れ，窒素気流下 で24 時間加温還流処理した。反応終了後，放冷，ろ 過水洗し, 乾燥後, 前処理炭とした。

2.3 金属イオンの分析

前処理によりろ液中に溶出した金属イオン(カルシ ウム, マグネシウム, 鉄, 亜鉛, マンガンの 5 金属) 
Table 1 Particle size and elemental analyses of coals

\begin{tabular}{l|c|ccccc}
\hline & Particle & \multicolumn{5}{|c}{ Ultimate analyses (d. a. f. \%) } \\
& Size (mesh) & $\mathrm{C}$ & $\mathrm{H}$ & $\mathrm{N}$ & $\mathrm{S}$ & Ash \\
\hline Aberdare & $<200$ & 82.8 & 5.4 & 1.6 & 0.4 & 16.0 \\
Miller & $<100$ & 82.4 & 7.2 & 1.9 & 0.6 & 15.8 \\
Mowell & $<60$ & 61.4 & 4.9 & 0.7 & $\ldots$ & 2.3 \\
\hline
\end{tabular}

Table 2 Pre-treatment procedures

\begin{tabular}{c|l|c}
\hline abbeviation*1 & treatment solvents & $\begin{array}{c}\text { reaction time } \\
\text { (h) }\end{array}$ \\
\hline (A) & $1 \mathrm{M}-\mathrm{CH}_{3} \mathrm{COONH}_{3}$ & 24 \\
(B) & $1 \mathrm{M}-\mathrm{CH}_{3} \mathrm{COOH}$ & 24 \\
(C) & $1 \mathrm{~N}-\mathrm{HCl}+\mathrm{CH}_{3} \mathrm{OH}^{* 2}$ & 24 \\
\hline
\end{tabular}

*1 : Pre-treatment at refluxing temperature

*2 : $\mathrm{CH}_{3} \mathrm{OH} / 1 \mathrm{~N}-\mathrm{HCl}=10(\mathrm{~V} / \mathrm{V} \%)$

について定量分析を行った。カルシウム，マグネシウ ムイオンの分析法はマスキング剂としてランタン $(0.5 \%$ 溶液)をろ液に $10 \%$ 添加し，それ以外の金属イ オンについてはそのまま直接, 原子吸光法により定量 した。

原炭についても Table 2 に示すように，100ccビー カ一内に原炭試料(約 $0.5 \mathrm{~g}$ ) を入れ，61\%硝酸 $10 \mathrm{ml}$ お よび $31 \%$ 過酸化水素水 $5 \mathrm{ml}$ を添加後, 約 6 時間ホット プレート上で加熱し有機成分を酸化分解した。放冷後, 酸分解物はNo.5C 万紙でろ過，水洗し，乃液をホッ トプレート上で半乾固後, 少量の希硝酸水溶液に加温 溶解後, $200 \mathrm{cc}$ メスフラスコに移し， $0.24 \mathrm{~N}$-塩酸水 溶液により標線まで希釈した。これら抽出液中の無機 分は, 上述の操作により定量した(JIS K0102参照)。

\section{4 灰分の調製}

2.4 .1 低温灰化:原炭および脱鉱物質前処理炭は プラズマ灰化装置 (Yanako LTA-154) を用い, 酸素 流量 $150 \mathrm{~m} l / \mathrm{min}$ で170W-24 時間低温灰化した。低 温灰化後，残った鉱物質の形状，組成を走査一分析型 電子顕微鏡により観察した。このような低温灰化処理 により，石炭内の鉱物質を最小の変化で採集でき る16) 19)。

2.4 .2 微粉炭燃焼試験: Mowell 炭を, Fig. 1 亿 示したフレームレス微粉炭然焼に供した。微粉炭燃焼 は微粉炭を運搬するキャリアーガスとして空気 2-3 l $/ \min$ および然焼用空気として $10 \ell / \min$ の混合空気 を予熱器で約 $700^{\circ} \mathrm{C}$ に予熱して燃焼に用いた。原炭, 前 処理炭についておのおの $40-80 \mathrm{~g}$ を $5 \mathrm{~g} / \mathrm{h}$ の量づつ流動
(1)

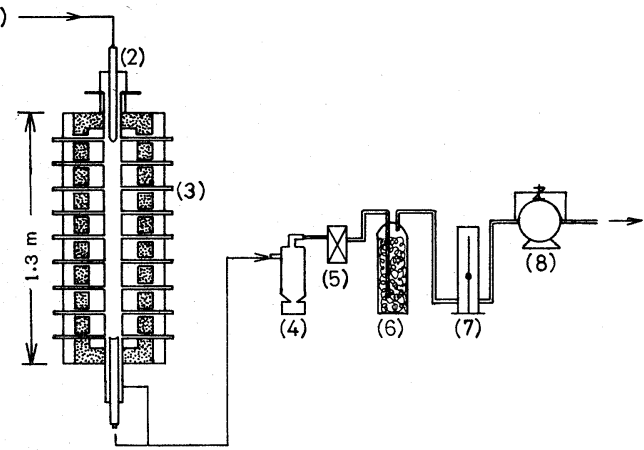

(1)sampling feeder, (2)water cooled burner, (3) electric furnace, (4)cyclon, (5)quartz filter, (6) glass fiber, (7)flow meter, (8)air pump

Fig. 1 Schematic diagram of pulverized coal combustion

炉内に自動吸引(1), 噴霧させ $(2)$, バーナーから出口迄 $1.3 \mathrm{~m}$, 炉内温度 $1200^{\circ} \mathrm{C}$ の炉内 $(3)$ を通過させた。炬内 のガスの平均滞留時間は 1.3 秒であった。燃焼により 生成したF.A.はサンプリングプローブを通り，サイ クロン(4)およびその後の円筒石英フィルター(5)により 2 段階捕集した。これら燃焼生成物をサイクロンF.A. (I)，フィルターF.A. (II)で捕集し，その収率をおのお の測定した。

2.4 .3 F.A.の分析

(a)粒径分析: 原炭, 前処理炭を低温灰化処理し, 生 成した鉱物質の粒径分布を測定した。測定はFig. 2 に 示した粉じん除去管(1)をつけたプラスチック製の容器 


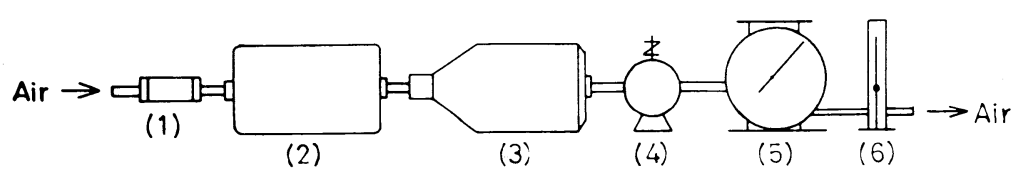

(1) absorbent cotton, (2) sample vessel, (3) Andersen Stack Sampler

(KANOMAX, MODEL5660), (4)air pump, (5)gas metter, (6)flow meter

Fig. 2 Schematic diagram for the measurement of size distribution for mineral matters obtained from coals

Table 3 Mineral quantities containing original coals

\begin{tabular}{lcrrrrrrrr}
\hline & & & \multicolumn{7}{c}{$\%$} \\
& $\mathrm{Si}$ & $\mathrm{Al}$ & $\mathrm{Ca}$ & $\mathrm{Fe}$ & $\mathrm{Mg}$ & $\mathrm{Mn}$ & $\mathrm{Ti}$ & $\mathrm{P}$ & $\mathrm{S}$ \\
\hline Aberdare & 66.0 & 28.4 & 0.6 & 1.5 & 0.2 & $<0.1$ & 3.0 & 0.1 & 0.1 \\
Miller & 62.4 & 25.4 & 1.2 & 7.9 & 0.3 & 0.2 & 1.7 & 0.2 & 0.6 \\
Mowell & 16.2 & 9.9 & 36.2 & 14.1 & 9.9 & 0.2 & 0.5 & 0.1 & 12.7 \\
\hline
\end{tabular}

(I)

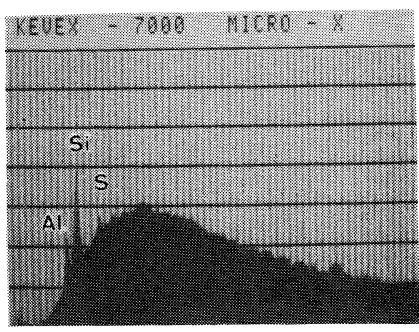

(1)

(I)

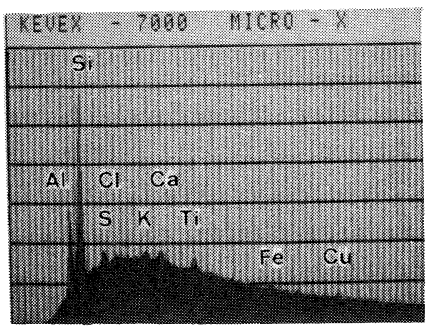

(1)

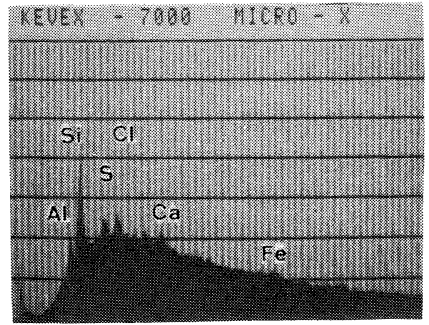

(2)

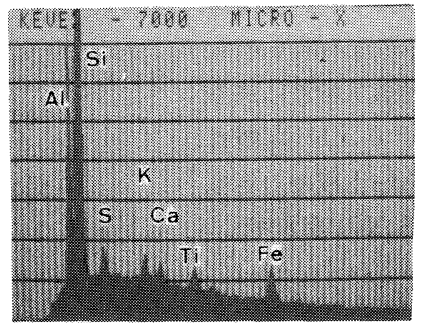

(2)

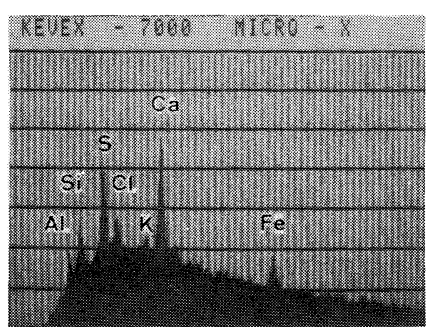

(3)

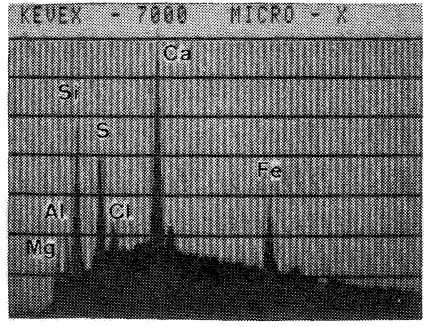

(3)

(1) Aberdare coal (2)Miller coal (3) Mowell brown coal

Fig. $3 \mathrm{X}$-ray diffraction of original coals $(\mathrm{I})$ and minerals (II) in original coals prepared through low temperature ashing

内(2)におのおの 300-500mg の鉱物質を入れバイブ レーターにより振動, 分散しつつ, 吸引流量 $18 \ell$ / minで10分間, アンダーセンスタックサンプラー(3) 内(多段階にろ紙を重ねたアンダーセン内に粉じんを 一定流速下で吸引し，その慣性衝突により粉じんの粒 径を分別する)に吸引，分別して行った。なお，粒径 分布は次式で表示した。
$\mathrm{f}(\mathrm{D})=\Delta \mathrm{m} /\left(\log \mathrm{D}_{\mathrm{p}}-\log \mathrm{D}_{\mathrm{p}-1}\right)$ $\Delta \mathrm{m}$ : 粒径が $\mathrm{D}_{\mathrm{p}}$ から $\mathrm{D}_{\mathrm{p}-1}(\mu \mathrm{m})$ の粉じんの重量 $(\mathrm{g})$ $\mathrm{D}_{\mathrm{p}}$ : 粒子の粒径 $(\mu \mathrm{m})$, ここで $\mathrm{D}_{\mathrm{p}}>\mathrm{D}_{\mathrm{p}-1}$

(b)形状，組成の分析:原炭，前処理炭中の鉱物質およ びこれらの低温灰化処理により生成した鉱物質を透過 一走査一分析型の複合型電子顕微鏡 (JEOL JEM-1200EX, ASID-10, KEVEX-7025J)により, 粒子の形状, 組成を 
Table 4 Ash yield (\%) of original and de-ashing pretreated coals by plazma asher

\begin{tabular}{l|rccr}
\hline & Orig. & (A) & (B) & (C) \\
\hline Aberdare & 17.9 & 16.5 & 15.8 & 14.8 \\
Miller & 16.9 & $\ldots$ & $\ldots$ & 8.8 \\
Mowell & 6.0 & 1.9 & 0.9 & $<0.5$
\end{tabular}

Orig : Original coal

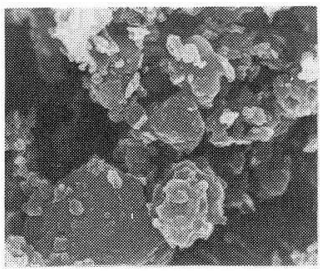

(1)

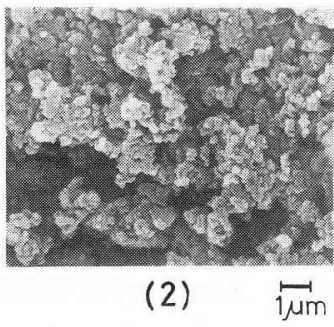

Fig. 4 Scanning Electron Microscope (SEM) photographs of minerals in Aberdare coal (1) and Mowell brown coal(2) prepared through the low temperature ashing
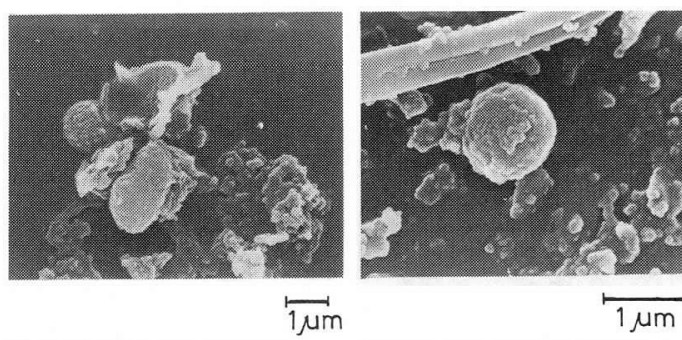

Fig. 6 SEM photographs of spherical minerals in Mowell brown coal prepared through the low temperature ashing

\section{3. 結 果}

3.1 原炭中の鉱物質粒子

原炭中の鉱物質の工業分析値をTable 3 に, 原炭の X線分析結果をFig. 3-(I)に示す。

Table 3 より Aberdare 炭はケイ素,アルミニウム を主成分とし，鉱物質全体の約 $95 \%$ を占めた。 Miller炭はこれら元素の他に, 若干, カルシウム, 鉄 を含有していた。

Mowell 褐炭は主成分としてカルジウム
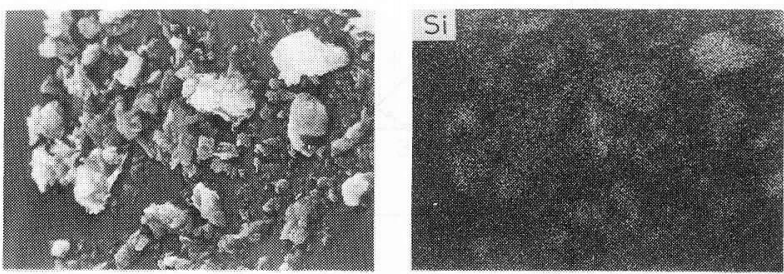
を含有していた。他に鉄, マグネシウムが 多く含まれていた。シリカ,アルミニウム はAberdare, Miller 炭と比較し, 鉱物質 全体の 26\%と僅かであった。これは石炭 全体に対し，僅か $0.6 \%$ になる。

なおこれら石炭のX線分析結果も工業 分析值と類似のスペクトルを示した ( Fig. 3-(I))。Aberdare炭, Miller炭ではシリカ, アルミニウムの強いピークが認められた。 一方, Mowell 炭ではカルシウムが最も強 いピークを示した。ピーク強度の順はカル シウム>ケイ素>アルミニウム>イオウ> 鉄〉塩素>マグネシウムであった。原炭中 の鉱物質の粒径を走査型電子顕微鏡で観察 することは困難であった。

\section{2 原炭の低温圧化鉱物質}

原炭の低温兏化処理による扊化収率を Table 4 に示した。Aberdare, Miller, Mowell 炭共に灰化收率はおのおの $17.9 \%$ ，

測定した。また，X線分析およびイメージセレクター による各元素のマッピング分析は, 加速電圧 $60 \mathrm{Kev}$, フィラメント電流值約 $50 \mu \mathrm{A}$, 試料傾斜角 $30^{\circ}$ の同一 条件下, 低倍率 $(\times 1,000$ 倍) で試料面の広域に対し て行った。
$X$-ray Spectrometer (EDS) elemental maps of minerals in Aberdare coal prepared through the low temperature ashing
16.9\%，6.0\%であった。Aberdare, Miller, Mowell原炭から低温灰化により生成した鉣物質のX 線分析, 走査電子顕微鏡像およびそのX線イメージ像 をおのおの Fig. 3(II)，4，5に示した。

㳪青炭: Aberdare, Miller両炭の低温灰化物には, X線分析(Fig. 3-(II))から, 共にイオウイオン, 塩素イオ 

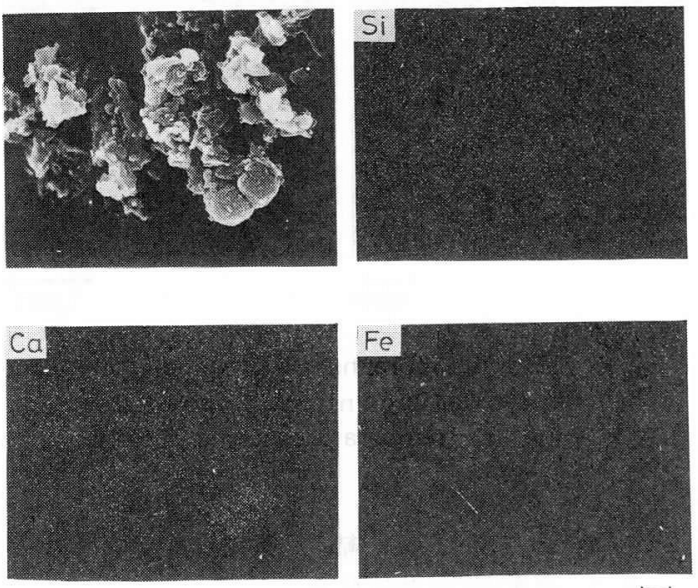

$\stackrel{\longmapsto}{1 \mu \mathrm{m}}$

Fig. 7 SEM photograph and EDS elemental maps of minerals in Mowell brown coal through low temperature ashing

ンなどの陰イオンが残留しており，原炭中の鉱物質と 低温灰化後の鉱物質の組成の差はきわめて小さかった。 また，Aberdare 炭は粒径 5-20 $\mu \mathrm{m}$ の大粒子が多く認 められた。1 $\mu \mathrm{m}$ 以下の微小粒子はほとんど認められ なかった(Fig. 4-(1))。Aberdare炭から低温灰化によ り生成した鉱物質のX線イメージ像では，鉱物質はほ とんどがケイ素打よびケイ素ーアルミニウム系の大粒 子として観察された(Fig. 5)。一方，Miller炭では一 部， $1 \mu \mathrm{m}$ 以下の微小粉じんが混在した以外はAberdare 炭の鉱物質の形状と大差は認められなかった。 X線イメージ像による観察では, Miller炭はFig. 5 に 示したAberdare炭と同様の組成を示したが，これら 大粒子に加えてカルシウムーケイ素ーアルミニウムが混 合した微小粒子が若干認められた。

Mowell 褐炭: Mowell褐炭に打いても原炭中の鉱物 質と低温灰化後の鉱物の組成の差はさわめて小さかっ た(Fig. 3-(II))。Mowell 炭の低温灰化物はカルシウム を主成分とし，他にイオウ，鉄，マグネシウムの含有 も認められた。粒子は丸みを帯びた $1 \mu \mathrm{m}$ 以下のカル シウムの微粒子が凝集し合っているのが認められた (Fig. 4-(2))。カルシウム粒子以外にケイ素, アルミニ ウムからなる 5-20 $\mu \mathrm{m}$ の大粒子も観察されたが量的に は僅かであった(Fig. 3-(II))，Fig. 4-(2))。また，僅かな がら，粒径 $1 \mu \mathrm{m}$ 程度の不完全な球形および楕円形の カルシウム粒子も観察された (Fig. 6)。さらに, X 線 イメージ像 (Fig. 7) で詳細に観察すると灰分粒子はほ とんどが炭酸カルシウムの微小単独粒子であった。ま
た, Aberdare, Miller 炭に認められたケイ素, ケイ 素ーアルミニウム系の大粒子もほとんど認められなか った。

\section{3 粒径分布}

Aberdare, Miller 原炭の低温灰化鉱物質の粒径分 布をFig. 8に示した。

Aberdare, Miller 原炭の低温灰化鉱物質は共に粒 径 5-20 $\mu \mathrm{m}$ の大粒子が主であった。また両炭共 $5 \mu \mathrm{m}$ 以 下の粒子は鉱物質の約 $25 \%$ 程度であったが， $1 \mu \mathrm{m}$ 以 下の微小粒子において両炭では明らかに差異が認めら れた。Aberdare 炭では $2 \mu \mathrm{m}$ 以下の粒子が僅か $2 \%$ 以 下で， $1 \mu \mathrm{m}$ 以下は存在していないのに対し， Miller 炭では約 $8 \%$ 含まれ，0.5-1/ m に相当量が分布していた。10 $\mu \mathrm{m}$ 以上の大粒子はAberdare 炭の方が多い。このよ らに, Aberdare炭の低温灰化鉱物質はおもに大粒子

(I)

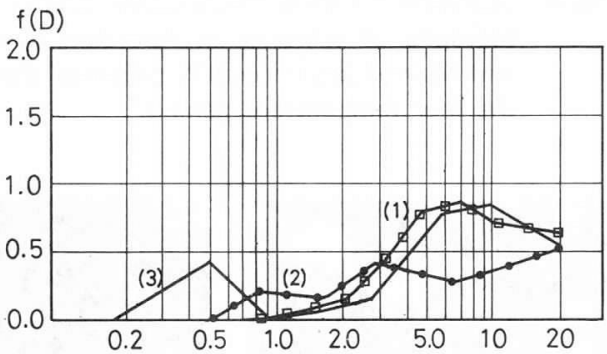

$f(D)$
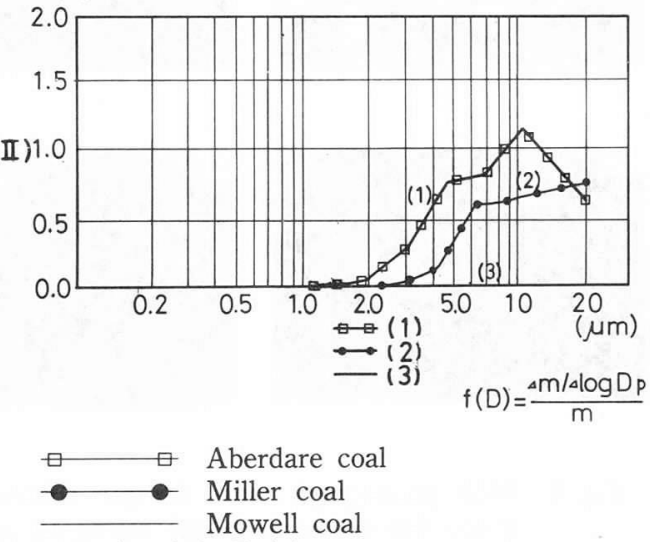

$\mathrm{f}(\mathrm{D})=(\Delta \mathrm{m} / \Delta \log \mathrm{Dp}) / \mathrm{m}$ $\Delta \log \mathrm{D}_{\mathrm{p}}=\log \mathrm{D}_{\mathrm{p}+1}-\log \mathrm{D}_{\mathrm{p}}$ $\mathrm{D}_{\mathrm{p}}$ : particle diameter $(\mu \mathrm{m})$ $\mathrm{m}$ : total mineral weight $\Delta \mathrm{m}$ :mineral weight amoung $\mathrm{D}_{\mathrm{p}+1}$ and $\mathrm{D}_{\mathrm{p}}$

Fig. 8 Size distributions for minerals in coals before(I) and after (II) the de-mineralizing pre-treatments prepared through low temperature ashing 
Table 5 Mineral ions quantities containing original coal and leaching from coal by refluxing pre-treatment for $24 \mathrm{~h}$

\begin{tabular}{lc|rrrrr}
\hline & & $\mathrm{Ca}$ & $\mathrm{Mg}$ & $\mathrm{Zn}$ & $\mathrm{Mn}$ & $\mathrm{Fe}$ \\
\hline Aberdare & Orig.*1 & $100 * 2$ & 100 & $\ldots$ & $\ldots$ & 2300 \\
& (C)*3 & 70 & 110 & 30 & 5 & 930 \\
\hline Miller & Orig. & 1300 & 420 & $\ldots$ & $\ldots$ & 4420 \\
& (C) & 780 & 480 & 40 & 80 & 4210 \\
\hline \multirow{2}{*}{ Mowell } & Orig. & 7800 & 3200 & $\ldots$ & $\ldots$ & 1750 \\
& (A) & 6700 & 2600 & $\ldots$ & $\ldots$ & $<10$ \\
& (B) & 7100 & 2950 & $\ldots$ & $\ldots$ & 800 \\
& (C) & 7310 & 2890 & 30 & 20 & 1480 \\
\hline
\end{tabular}

*1 : Original coal

$* 2$ : Mineral ion $(\mu \mathrm{g}) / \operatorname{coal}(\mathrm{g})$

*3 :refluxing pre-treatment for $24 \mathrm{~h}$

(A) by $1 \mathrm{M}-\mathrm{CH}_{3} \mathrm{COONH}_{4}$

(B) by $1 \mathrm{M}-\mathrm{CH}_{3} \mathrm{COOH}$

(C) by $1 \mathrm{~N}-\mathrm{HCl}$ containing methanol

からなり, Miller炭の鉱物質では大粒子から微粒子側 へと広い粒径分布を示した。

Mowell 炭の鉱物質の粒径分布をFig. 8 に示した。 Mowell 炭では鉱物質の粒径分布は二山形となった。 大粒子は約 $10 \mu \mathrm{m}$ の粒子を中心に分布し，小粒子は $0.5 \mu \mathrm{m}$ を中心に 0.2-1 $\mu \mathrm{m}$ の範囲に分布している。こ のよらに粒度分布は前節に示したX線イメージ像の結 果と合致している。

\section{4 石炭の脱鉱物質前処理効果}

\section{4 .1 金属イオン溶出量}

脱鉱物質前処理による鉱物質溶出量をTable 5 に示 す。Aberdare炭のカルシウム，マグネシウムの含有 量はきわめて少なく, したがって前処理により溶出す る金属イオン量も極めて少なかった。また，石炭中に 含有する鉄の量は他の石炭と同程度であったが，前処 理 (C処理)により溶出した鉄イオンの量は石炭含有量 の $40 \%$ 程度に留まった。

Miller 炭はAberdare 炭と同程度の石炭化度である が, Aberdare炭よりもカルシウム, 鉄の含有量が多 い。脱鉱物質前処理 ( $\mathrm{C}$ 処理)によりカルシウムの約 $60 \%$ が溶出した。一方, マグネシウム, 鉄はそのほ とんどが溶出した。

Mowell 炭では前処理効果が顕著に認められた。石 炭中に含有されるカルシウム, マグネシウムはそのほ とんどがイオン交換性の有機酸塩であるとされている が14)20)21), 前処理 (C 処理)によりそのほとんどが除
去された。

\section{5 脱鉱物質前処理炭の低温灰化鉱物質}

3.5 .1 灰化収率

前処理後の石炭の低温灰化収率をTable 4 に示した。 Aberdare炭では何れの前処理法によっても, 灰化収 率に2-3\% 程度の減少しか認められなかった。 Miller 炭はAberdare 炭と比較し前処理 (C処理)による兏化 収率の減少が顕著に認められ, 原炭の $16.9 \%$ から $8.8 \%$ へと, 半分程度に減少した。

Mowell 炭では前処理による鉱物の除去量は著しく 高く, 前処理(A)により鉱物質全体の約 $70 \%$, 前処理 (B)で約 $85 \%$ が除去された。さらに強力な前処理(C)を 施すと低温灰化後の鉱物質はほとんど残らなかった。 この結果はTable 5 のカルシウム, マグネシウム, 鉄 の除去量と一致していた。

\section{5 .2 低温灰化鉱物質の形状と組成}

Aberdare 炭は前処理前後で形状, 組成にほとんど 差は認められなかった。Miller炭では原炭のX線スペ クトルに認められたごく小さなカルシウムのピークが 前処理により消失した。また， $1 \mu \mathrm{m}$ 程度の微小粒子 が消失した。

Mowell炭では原炭で認められた $1 \mu \mathrm{m}$ 以下の微小粒 子が，前処理(A)によりかなり消失し，その代わりにこ れら微小粒子が集合, 融着し合ったような, 形が不揃 いの 1-5 $\mu \mathrm{m}$ 程度の中粒子が混在して認められた。前 処理(B)は(A)処理とほぼ同じ結果を与えた。さらに強力 
Table 6 Ash yields of Mowell brown coal before and after de-mineralizing pre-treatment by fluidized combustion process

\begin{tabular}{l|rr|r}
\hline & (I) & (II) & \multicolumn{1}{c}{ (III) } \\
\hline Orig. & 0.36 & 0.39 & 0.75 \\
(A) & 0.09 & 0.13 & 0.22 \\
(B) & 0.07 & 0.07 & 0.14 \\
(C) & $<0.05$ & $<0.05$ & $<0.10$ \\
\hline
\end{tabular}

Orig. : Original coal

(I) : cyclon ash (W/W\%)

(II) : glass fiber thimble ash (W/W\%)

(III): total ash $(\mathrm{W} / \mathrm{W} \%)$

な酸を用いた(C)処理では，粒径にかかわりなく灰化粒 子はほとんど認められなくなった。

\section{5 .3 粒径分布}

秨青炭: 脱鉱物質前処理を施した石炭を低温灭化処 理した。灰化収率と粒径分布をTable 4，Fig. 8 亿示 す。Aberdare 炭に最も強力な前処理 ( C 処理)を施し ても前処理前後で鉱物質の収率および粒径分布にはほ とんど変化は認められなかった。一方, 前処理により Miller 炭では 1-5 $\mu \mathrm{m}$ の微小粒径領域に僅かな減少が 認められ，2-3 $\mu \mathrm{m}$ 以下の微小灰分が完全に消失した。

Mowell 炭では脱鉱物質前処理 (C処理)によりすべ
ての粒径領域で，鉱物質は完全に消失した。A処理 あるいはB処理であっても，残留灰分は少なく，粒径 分布測定に供することができる量はなかった。

\subsection{Mowell褐炭の微粉炭燃焼試験}

Mowell 原炭および一連の脱鉱物質前処理炭につい て小型流動床による微粉炭燃焼試験を行い, 生成した サブミクロン粒子をサイクロンフィルターおよび石英 円筒フィルターにより2段捕集した。

\section{6 .1 灰化収率}

Table 6にサブミクロン粒子の収率を示す。原炭で は $0.75 \%$ の.A.が発生した。酢酸アンモニウム処理 炭(A)ではその約 70\%，酢酸処理炭(B)では $80 \%$ 以上の F.A.が除去された。さらに，脱鉱物質効果が最も高 いメタノール添加の塩酸処理炭(C)においては, F.A. はほとんど残留しなかった。この傾向はサイクロン F.A., フィルターF.A.の何れでも同様であった。ま た,この流動床試験による死化収率は, 上述の低温灰 化による死化収率結果 (Table 4) とよい一致を示した。

3.6 .2 サブミクロン粒子の形状と組成

原炭の燃焼で生成したサイクロン-F.A.の走査像, X 線イメージ像およびX線分析結果をFig. 9 に示す。粒 子はその多くが粒径 $1 \mu \mathrm{m}$ 前後の完全な球形粒子であ った。ほとんどすべての粒子がカルシウム単独の粒子 であり, ケイ素, アルミニウム, 鉄などもカルシウム と共存した形態が僅かに含まれていた。 X線分析から
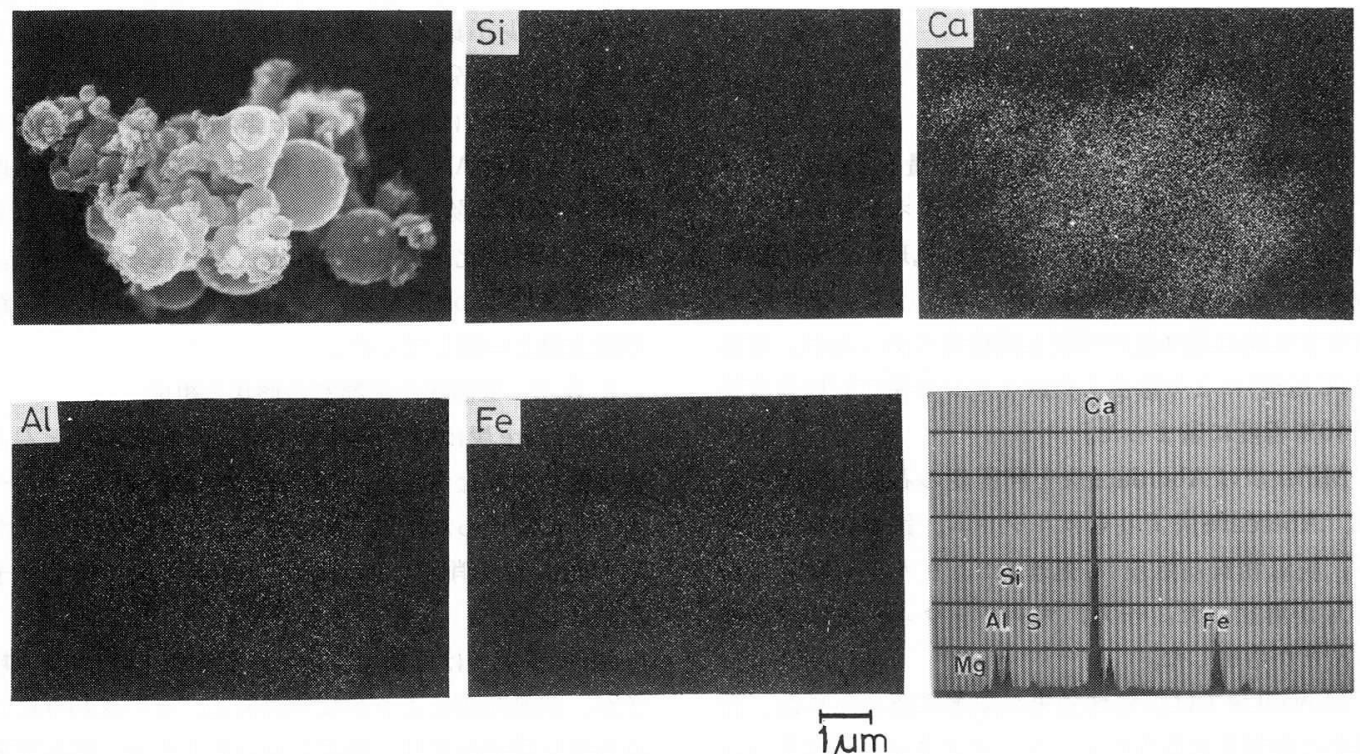

Fig. 9 SEM photograph, EDS elemental maps and $X$-ray diffraction of fly ashes derived from Mowell brown coal prepared through pulverized coal combustion 
I)

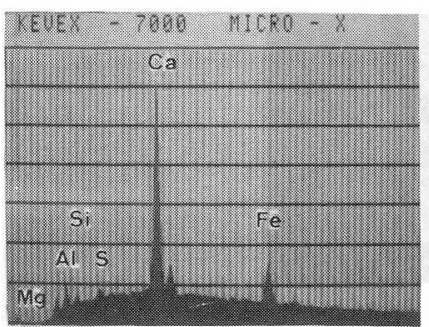

Orig.

(II)

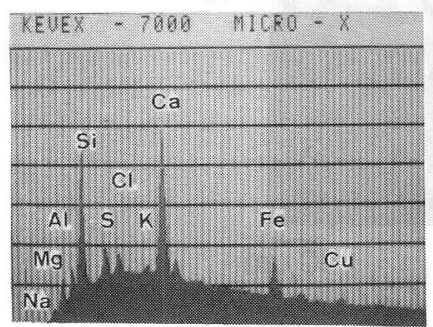

Orig.

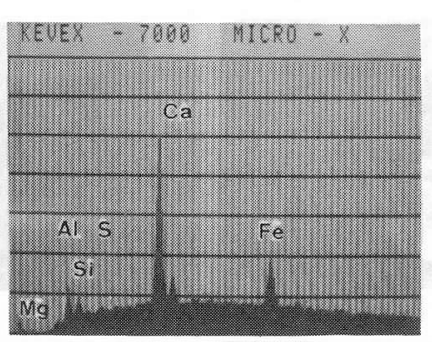

(A)

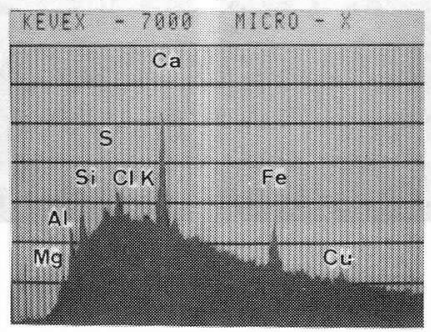

(A)

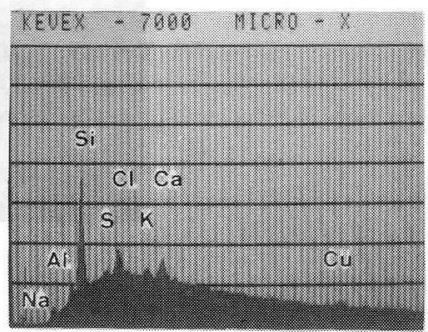

(B)

(I)fly ashes in cyclon (II)fly ashes in quarty filter Refluxing pre-treatments for $24 \mathrm{~h}$

$\begin{array}{ll}\text { (A) by } 1 \mathrm{M}-\mathrm{CH}_{3} \mathrm{COONH}_{4} & \text { (B) by } 1 \mathrm{M}-\mathrm{CH}_{3} \mathrm{COOH}\end{array}$

Fig. 10 X-ray diffraction of fly ashes derived from Mowell brown coal before and after the de-mineralizing pre-treatment prepared through pulverized coal combustion

も，主成分はカルシウムであり，他の含有元素として

鉄, ケイ素(鉄>ケイ素)が含まれている。

サイクロン-F.A. , フィルターF.A.のX線分析結 果をFig.10に示した。サイクロンーF.A.とフィルター -F.A.の主要鉱物質粒子は粒径分布にやや差があるも のの, 形状, 組成は類似し, サイクロン, フィルター F.A. 共に主成分はカルンウムであった。サイクロン F.A.の粒子は大部分が $1 \mu \mathrm{m}$ 以下であったが， $1-2 \mu \mathrm{m}$ 程度の粒径のものも相当存在し, 一部 3-5 $\mu \mathrm{m}$ の粒子 も認められた。フィルターF.A.の粒子はほとんど $1 \mu \mathrm{m}$ 以下の粒子であった。組成的にはフィルター -F.A. (Fig . 10-(II)) はサイクロン-F.A. (Fig. 10-(1)) と比べ, ケイ素, 鉄, イオウ, アルミニウムなどを多 く含んでいた。また，フィルターF.A.中に一部，鉄 を主成分とした粒径 20-100 $\mu \mathrm{m}$ 程度の大粒子が観察さ れた(Fig. 11-(a)，(b))。これら粒子は何れも鉄一カルシ ウム系の粒子であり，カルシウム粒子に鉄が凝縮して 大粒子を形成して扣り，あるいはそれら粒子が合体し て大粒子を形成しているのが観察された。なお，

F.A.中に未燃焼炭は認められなかった。

\section{4. 議 論}

F.A. 中のサブミクロン粒子の生成機構は序に述べ
たように，(1)石炭中の鉱物粒子が開裂粉化して生じた 微粒子，(2)原型のまま排出された石炭中の鉱物質微粒 子, (3)石炭中の鉱物質が揮発㠜集した微粒子とがあり らる312)。これらの機構中，どれが主要であるかは原 炭あるいは低温灰化後の鉱物質の形状組成を燃焼灰分 のそれらと比較することによって明らかにできる。原 炭中の鉱物質組成, 粒度を正確に把握することは石炭 有機質の妨害により容易ではないが，直径 5-20 $\mu \mathrm{m}$ の 石炭中の鉱物粒子については, 低温灰化後の鉱物の組 成とほほ一致しており，低温灰化は原炭鉱物質を最小 の変化で灰化できたと思われる。このような，稳和な 灰化によりすでに $1 \mu \mathrm{m}$ 以下の微小粒子が，石炭によ っては生成していることから，(1)の機構は主要とは考 壳られない。

一方，石炭に対してイオン交換あるいは酸抽出を行 らとMiller炭, Mowell炭においてはサブミクロンの 微小粒子が低温灰化鉱物から顕著に減少あるいは消失 する。サブミクロン粒子はおもにカルシウムからなり， それに微量のケイ素, アルミニウムなどの元素が付随 した組成となっている。さらに, 本研究で調べた 3 炭 種では溶出カルシウムイオンが多い石炭 (Mowell $>$ Miller $>$ Aberdare) 程, サブミクロン粒子 

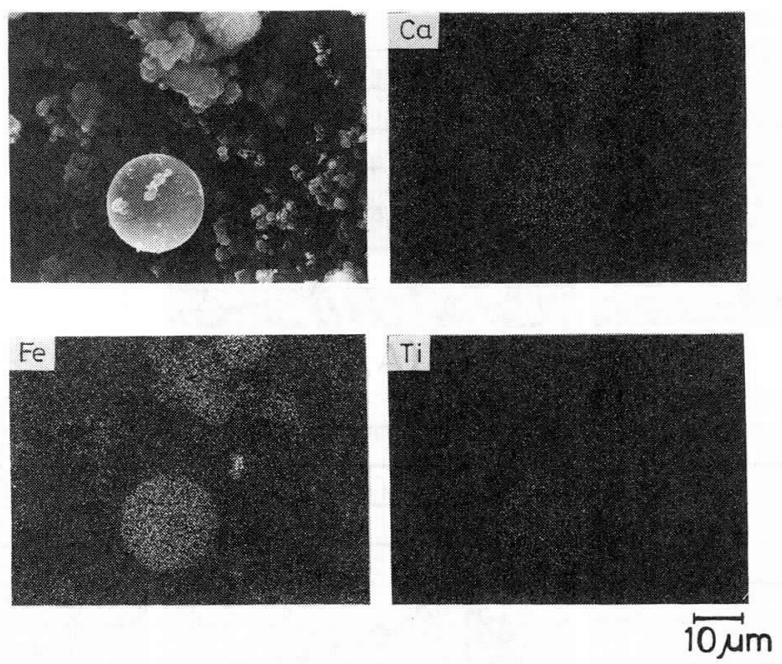

(a)
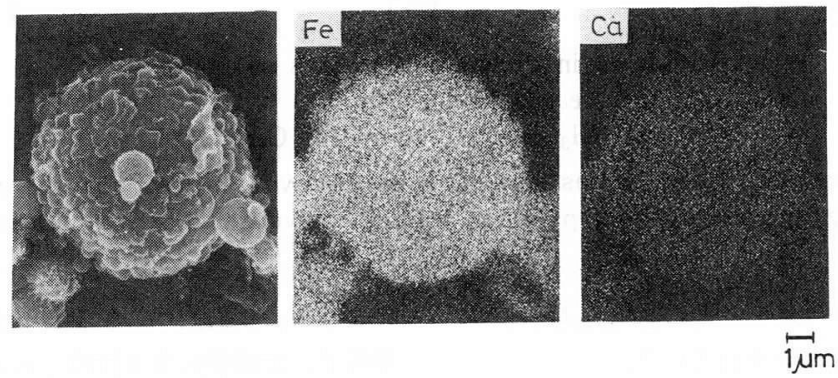

(b)

Fig. 11 SEM photograph and EDS elemental maps of fly ashes containing iron derived from Mowell brown coal

が多く生成している。さらにカルシウムイオンを含ま ないAberdare 炭の灰分の形状は脱鉱物質前処理に影 響されない。これらの事実は灰分中のサブミクロン粒 子が主としてイオン交換性のカルシウムイオンから生 成する(3)の機構が重要であることを示唆している3)12)。

ところで石炭中のカルシウムは硫酸カルシウム, 炭 酸カルシウム, 酸化カルシウムおよび石炭中の有機含 酸素官能基とイオンあるいはキレート結合した架橋イ オンなどが推定される13) 15)22) 24)。これらのカルシ ウムイオンは塩酸のような強酸で処理すれば硫酸カル シウム以外は溶出するため, (1)と(3)の機構の区別はで きないが，中性の酢酸アンモニウムや弱酸性の酢酸 (特に酢酸アンモニウム) では炭酸カルシウムや酸化カ ルシウムの除去は難しく, 専ら架橋イオンがイオン交
換により除去されるだけと考えられる。一方これら 溶媒を用いた処理により，Mowell炭中の $70 \%$ 以上の カルシウムイオンが除去され，かつ，サブミクロン粒 子が顕著に減少することから, 同炭のカルシウムは Durie ${ }^{20) 21)}$ が報告しているように主として架橋イオン であり，サブミクロン生成の主たる原因となっている ことが示される。したがって，サブミクロン粒子のお もな生成機構は(3)であるといえよう。

なお，塩酸処理ではMowell炭から灰分が生成しな くなるので，石炭中のすべてのアルカリ土類金属およ び鉄鉱物が溶出されることを意味している。ところで， 灰分中にはカルンウムを主として含有する小粒子が凝 集して大粒子を形成しているのが認められるが，この ような大粒子は酢酸アンモニウムや酶酸による脱イオ 
ン前処理を施した後にも観察されることから，上述の カルシウム無機塩が凝集したのであろら。

Mowell 炭の微粉炭燃焼結果は以上の低温灰化の結 果とよく一致していることから，微粉炭燃焼において も上述の機構でサブミクロン粒子が生成するのであろ 5。

微粉炭燃焼で生成したフィルターF.A.の粒径はサ イクロンF.A. と比較して小さく, 組成もカルシウム 以外の元素が相対的に増加している。この内，一部は 揮発した元素が低温に設置されたフィルターで捕集さ れたカルシア上に凝縮したものであろう。一般にサイ クロンF.A.とフィルターF.A.を比較するとフィルター F.A.の方が溶出成分を多く含むことが知られてい る25)。また，とくに気化したイオウ分がカルシウム 粒子上に凝縮するとも報告されている26)27)。また， F.A. 中に残留するイオウ分は粒径 $5 \mu \mathrm{m}$ 以下の微粒子 側に多く含まれるともいわれている28)。このような イオウ分を多く含む微小なフィルターF.A.は集じん 装置を通り拔け，大気中に放出され易いので，大気污 染防止対策の立場からも大きな問題となる。

以上，捕集が困難であり，かつ人体の健康への影響 が予測されるサブミクロンF.A.は主として石炭中の イオン交換性金属イオンが燃焼中に酸化物あるいは炭 酸塩となる過程で，その気相結晶成長が十分でない時 に生成すると推定できる。したがって，その生成を抑 制するには石炭中のイオン交換性金属イオンを除去す るか，燃焼時に粒径の大きな粒子に付着させるかの 2 通りが考兄られる。前者については石炭鉱物の全量を 除去することに比べれば，かなり容易である。一方， 鉄を主成分とする $20-100 \mu \mathrm{m}$ の大粒子が一部観察され たが，サブミクロン生成の一因子であるカルシウム小 粒子も，この大粒子に含有されていることから，石炭 燃焼過程でサブミクロン粒子の凝集，大粒子形成を促 寸鉄のバインダーとしての役割が推定できる。適当な 融着性の無機分と合体させることも，流動床燃焼であ れば可能であろう。

このよらなサブミクロン粒子の生成機構は亜瀝青炭 や褐炭の液化に際して運転トラブルとなる炭酸塩スラ ッジの生成機構およびその対策に共通することがわか る29)。気相と液化油/液化溶剈からなる液相とで鉱物 質の生成·生長の雾囲気は大きく異なるが，共通する 点が多いことは興味深い。

$$
\text { 文献 }
$$

1）環境庁企画調整局，“エネルギー転換期の環境政 策”大藏省印刷局, p.39(1981)
2) 岡崎 健, 西川 隆, 大竹一友, 化学工学論文集, 10, 751(1984)

3）定方正穀，黒沢靖志，新井忠男，斎藤淳一，吉野 淳, 佐賀井 武, 化学工学論文集, 10,150 (1984)

4）伴 豊, 渡辺征夫, 古谷圭一, 松下秀鶴，合志 陽一，分析化学，34，264(1985)

5) "Control Techniques for Particulate Air Pollutants,"U. S. EPA., Publication, p.51 (1969)

6) Roger, J. C., Volker, A. M., Thomas, T. S., Michael, C. and John, B. H., Journal of the Air Pollution Control Association, 26, (8), 787 (1976)

7) Fisher, G. L., Prentice, B. A., Silberman, D., Ondov, J. M. and McFarland, A. R., Environmental Science and Technology, 12, 447 (1978)

8) Henry, W. M. and Knapp, K. T., Env. Sci. Tech., 14, (4) , 450(1980)

9）環境庁企画調整局, “エネルギー転換期の環境政 策”大藏省印刷局, p.79 (1981)

10) Aranyi, C., Miller, F. J., Andres, S., Ehrlich, R. and Fenters, J., Environmental Research, 20 , 14(1979)

11) 外山敏夫, 労衝衛生工学会 (シンポジウム), エー ロゾルに関する論文集，p.81（1962）

12) McCrone, W. C. and Delly, J. G., The Particle Atlas, Ann Arbor Science, Ann Arbor, Michigan, vol. 1-4 (1973)

13）持田 勲, 下原孝章, 光来要三, 藤津 博, 竹下 健次郎, 燃協誌, 62，246(1983)

14）下原孝章，持田 勲，燃協誌，66，135(1987)

15) Mochida, I., Shimohara, T., Korai, Y., Fujitsu, H. and Takeshita, K., Fuel, 62, 659 (1983)

16）横山慎一, 奥谷 猛, 長谷川義久, 吉田諒一, 石 井忠雄，燃協誌，59，636(1980)

17) Gluskoter, H. J., Fuel, 44, 285 (1965)

18) O'Gorman, J. V. and Walker, P. L. Jr., Fuel,50, 135 (1971)

19）長谷川義久，上田 成，前河涌典，佐藤俊夫，燃 協誌，52，917(1973)

20) Durie, R. A., Fuel, Lond., 40, 146 (1961)

21) Brown, H. R. and Durie, R. A., Fuel, Lond., 40, 207 (1961) 
22）持田 勲，下原孝章，燃協誌，63，387(1984)

23) Mochida, I., Shimohara, T., Korai, Y. and Fujitsu, H., Fuel, 63, 847(1984)

24) Mochida, I., Moriguchi, Y., Shimohara, T., Korai, Y., Fujitsu, H. and Takeshita, K., Fuel, 62,471 (1983)

25）渡辺征夫, 田辺 潔, 古谷圭一, 松下秀鶴, 分析 化学, 34, 45(1985)

26) Davis, W. T. and Fiedler, M. A., J. Air Pollut.
Contr. Ass., 32, 395(1982)

27) Reed, G. D., Davis, W. T. and Pudelek, R. E., Environ. Dci. Technol., 18,548 (1984)

28) Sadakata, M. and Sakai, T., Emission of submicron carbon from pulverized coal combustion system Comb. \& Flame (accepted)

29) Mackay, G. H., Camier, R. J. and Perry, G. J., Fuel, 64, 568 (1985)

\title{
A Mechanistic Study on the Formation of Submicron Fly Ashes in the Pulverized Coal Combustion
}

\author{
Takaaki SHIMOHARA*1, Takashi ANDO*2, Isao MochIDA*2 \\ $\left(\begin{array}{l}{ }^{* 1} \text { Fukuoka Environmental Research Center } \\ { }^{* 2} \text { Institute of Advanced Material Study, Kyushu University }\end{array}\right)$
}

SYNOPSIS :-Minerals in the pulverized coals (two bituminous and one brown coals) and fly ashes prepared through their low temperature ashing and pulverized combustion were compared in terms of their particle size distribution and elemental composition by means of scanning analytical electron microscope, $\mathrm{X}$-ray diffractometer and Andersen Stack Sampler in order to elucidate the mechanism of formation of submicron fly ashes in the pulverized coal combustion. The submicron fly ashes which were produced from coals of more calcium contents were found to consist principally of calcium regardless of coals and preparation procedures. No submicron minerals were found in the starting pulverized coals. The leaching of cations such as calcium, magnesium and iron with aq. $\mathrm{HCl}$ or aq. ammonium acetate markedly decreased the submicron fly ashes. No fly ash was found at all from the leached brown coal.

Such results indicate that submicron fly ashes are produced from ion-exchangable calcium cations bound to the organic portion of the coal through their insufficient coagulation during the combustion. Therefore the reduction of submicron fly ashes can be achieved by the removal of such cations by leaching coals or by trapping them on the partially fused surface of large fly ashes during the combustion.

\section{Key Words}

Fly ashes, Submicron, Electron microscopy, Minerals 